\title{
Resource Use Efficiency of Soybean in Belagavi District of Karnataka, India
}

\author{
K. Vasudeva Naik*, Vinayaka Jalikatti, Raghavendra Chourad and N. Ashok \\ UAS, Department of Agril Economics, B.Gudi, Dharwad, Karnataka, India \\ *Corresponding author
}

\section{A B S T R A C T}

\begin{tabular}{|l|}
\hline Ke y w o r d s \\
CD production function, \\
$\begin{array}{l}\text { Input use pattern, } \\
\text { Marginal factor cost and } \\
\text { marginal value product }\end{array}$ \\
\hline Article Info \\
\hline $\begin{array}{l}\text { Accepted: } \\
\text { 16 December } 2017 \\
\text { Available Online: } \\
\text { 10 January } 2018\end{array}$ \\
\hline
\end{tabular}

Introduction

Soybean (Glycine max) is a species of legume native to East Asia, it is an important global crop widely grown for its edible bean which has numerous uses. Soybean meal is a significant and cheap source of protein for animal feeds. Soybean is known as the "Golden bean" and "Miracle crop" etc, because of its several uses. It is an excellent source of protein and oil. It contains about 40 per cent of good quality protein. Besides utilization of Soybean as vegetable, it is also used in oil industry where it occupies first place in the world oil production. Soybean based food products are also suitable to diabetic patients as they contain less carbohydrates and low cholesterol. Therefore, it is one of the most economical protein sources in the world. It is a versatile crop with innumerable possibilities of improving agriculture and supporting farming industry (Ankita Parekh et al., 2012).

India ranked fifth after USA, both in area (11.604 million hectare) and production (8.569 million MT) in the world during 201516 (Ministry of Agriculture, Government of India). The area under the crop in the Karnataka state during 2015-16 was 113 thousand hectare, the production was 97 thousand tons and productivity was $852 \mathrm{~kg} / \mathrm{ha}$. Soybean has attained a prominent position in India's agro-economy with 12 per cent contribution. As the country is in short supply of edible oil and about 50 per cent of our 
edible oil consumption is fulfilled by imports of different vegetable oils, there is a direct need to promote the production of oil seeds like Soybean.

\section{World scenario}

Soybean was first introduced to Europe in the early 18th century and to British colonies in North America in 1765. It is a major oilseed crop in the world covering 91.29 million hectare under oilseed crops and contributing around 57 per cent (220.81MT) of the total oilseed production (390.39 MT) during 201011, which makes it as the leading oilseed crop in the world. The phenomenal increase in its area and production together with the expansion in processing units has earned a prominent position for India on the world map of Soybean industry. Major Soybean producing countries are United States (83.2 MT), Brazil (72 MT), Argentina (48 MT), China (13.5 MT) and India (12.55 MT). These countries contribute more than 90 per cent of global Soybean production. The average worldwide yield for Soybean crop in 2015 was 2.5 tons per hectare.

\section{Indian scenario}

India ranked fifth both in area (11.604 million hectare) and production (8.569 million MT) in the world during 2015-16 (Ministry of Agriculture, Government of India.). In India, Madhya Pradesh is the major producer of Soybean, which accounts for 58 per cent of the countries production (6.67 MT), followed by Maharashtra (4.32 MT), Rajasthan (1.12 MT) and Karnataka (0.15 MT). The area under the crop in the Karnataka state during 2010-11 was 113 thousand hectare, the production was 97 thousand tons and productivity was $852 \mathrm{~kg} / \mathrm{ha}$. During same period productivity in Andhra Pradesh was highest (1278 kg/ha) and Madhya Pradesh with $1021 \mathrm{~kg}$ per hectare yield was at second position. Average productivity of India was $1235 \mathrm{Kg}$ per hectare. Madhya Pradesh has emerged as the soy state of the country with over 55 percent share in area as well as $9^{\text {th }}$ in production. To the edible oil pool, Soybean has attained a prominent position in India's agro-economy with 12 per cent contribution. Earnings through Soybean meal export during 2015-16 were 43,857 million.

\section{Materials and Methods}

The present study was conducted in Belagavi district based on the major Soybean producing area in Karnataka, for study purpose primary and secondary data were collected. Primary data relating to costs and returns involved in production of Soybean from the selected farmers. Secondary data relating to area, production and productivity of Soybean and other relevant information for the study were collected. The multi-stage random sampling procedure was adopted to choose the sample farmers (respondents). In the first stage, Belagavi district was selected based on highest Soybean area. In second stage, taluks having highest area under Soybean were selected. In the third stage, for selecting respondents, four villages were selected randomly. In the fourth and final stage, 15 rural respondents from each village selected. Thus, in all, the study sample consists of 60 respondents. For this purpose, pre-tested and well-structured schedule were used.

The Cobb-Douglas type of production function was used to study the effect of various inputs on Soybean output. On account of its well-known property of its computational simplicity, justifies its wide application in analyzing production relations (Handerson and Quandt, 1971).

It being a homogenous function provided a scale factor enabling one to measure the returns to scale. The estimated regression 
coefficients represented the production elasticities. The form of Cobb-Douglas production function used in the present study is as follows.

$\mathrm{Y}=\mathrm{aX}_{1}{ }^{\mathrm{b} 1} \mathrm{X}_{2}{ }^{\mathrm{b} 2} \mathrm{X}_{3}{ }^{\mathrm{b} 3} \mathrm{X}_{4}{ }^{\mathrm{b} 4} \mathrm{X}_{5}{ }^{\mathrm{b} 5} \mathrm{X}_{6}{ }^{\mathrm{b} 6} \mathrm{X}_{7}{ }^{\mathrm{b} 7} \mathrm{e}^{\mathrm{u}}$. (1)

Where,

$\mathrm{Y}=$ Gross output in rupees

$\mathrm{a}=$ Intercept (efficiency) term

$\mathrm{X}_{1}=$ Expenditure on seeds (₹/ha).

$\mathrm{X}_{2}=$ Expenditure on Farm Yard Manure (FYM) (₹/ha).

$\mathrm{X}_{3}=$ Human labour expenditure $(₹ / \mathrm{ha})$.

$\mathrm{X}_{4}=$ Bullock labour expenditure (₹/ha).

$\mathrm{X}_{5}=$ Machine labour expenditure $(₹ / \mathrm{ha})$.

$\mathrm{X}_{6}=$ Expenditure on fertilizers $(₹ / \mathrm{ha})$.

$\mathrm{X}_{7}=$ Expenditure on Plant Protection Chemicals (PPC) (₹/ha).

$\mathrm{e}^{\mathrm{u}}=$ Error term

bi's $=$ Output elasticities of respective factor inputs, $i=1,2 \ldots .7$ and

The Cobb-Douglas production function was converted into log linear form and parameters (coefficients) were estimated by employing Ordinary Least Square Technique (OLS) as given below.

$\log Y=\log a+b_{1} \log X_{1}+b_{2} \log X_{2}+b_{3} \log$ $\mathrm{X}_{3}+\mathrm{b}_{4} \log \mathrm{X}_{4}+\mathrm{b}_{5} \log \mathrm{X}_{5}+\mathrm{b}_{6} \log \mathrm{X}_{6}+\mathrm{b}_{7} \log$ $\mathrm{X}_{7}+\mathrm{u} \log \mathrm{e}(2)$

The regression coefficients $\left(b_{i}\right.$ 's) were tested using ' $t$ ' test at chosen level of significance.

\section{Allocative efficiency}

Given the technology, allocative efficiency exists when resources are allocated within the farm according to market prices and it implies the proper level of input use in production. To decide whether a particular input is used rationally or irrationally, its marginal value products would be computed. If the marginal value product of an input just covers its acquisition cost it is said that is used efficiently.

The Marginal Value Products (MVP) was calculated at the geometric mean levels of variables by using the following formula....

$\operatorname{MVP} i^{\text {th }}$ resource $=b_{i} * \frac{\bar{Y}}{\bar{X}}$

Where,

$\overline{\mathrm{Y}}=$ Geometric mean of the output

$\bar{X}_{i}=$ Geometric mean of $i^{\text {th }}$ independent variable

$b_{i}=$ The regression coefficient of the $i^{\text {th }}$ independent variable

In order to determine, the efficiency of allocation of the resources or price efficiency, the value of the marginal product obtained by multiplying the marginal product $\left(b_{i}\right)$ by the price of the product was compared with its marginal cost.

A ratio of the value of marginal product to the factor price more than unity implied that the resources were advantageously employed. If the ratio was less than one, it suggested that resource was over utilized.

The criterion for determining optimality of resource use was, 
MVP/MFC > 1 underutilization of resources $\mathrm{MVP} / \mathrm{MFC}=1$ optimal use of resources MVP/MFC $<1$ excess use of resources.

\section{Results and Discussion}

Input Used pattern per hectare of Soybean cultivation in the study area are presented in Table 1. In the study area sample farmers cultivating Soybean only and hence the analysis is done for Soybean cultivation. It can be observed from the table that the average per hectare utilization of seed was $31 \mathrm{~kg}$. However, the average per hectare utilization human labour was 19 man days and the bullock labour used in study area was 3.22 pair days. Whereas, the tractor used in cotton cultivation was 2.50 hours. The Input like FYM, Fertilizer and PP Chemicals were used at the rate of 1.75 Tonnes, $645.50 \mathrm{Kg}$ and Rs, 225 respectively.

\section{Labour utilization and management}

The result presented in Table 2 revealed that around 19 human labour, 3.22 pair of bullocks and 2.52 hour of machine labour per acre.
Among various operations of Soybean the Loading, transportation, spreading organic manure, Sowing, Fertilizer application and weeding used the equal unit of 3 man days. However, the bullock labour utilization pattern in soybean cultivation was 1.22 man days for ploughing and 2 man days for sowing and in case of machine labour 1.5 ploughing and 1 for harrowing.

The estimates of the production function were presented in Table 3. The variables included in the function explained 92.64 per cent of the variation in production of soybean cultivation. The regression coefficient of seed (-0.41) Machine labour (-0.16) and fertilizer was negative, indicating that increase in use of seeds, machine labour and fertilizer reduction in gross returns hence it is advisable to reduce applicable of these inputs.

However, the regression coefficient of Human labour, bullock labour, fertilizer and PP Chemicals were showing significant hence it indicating increase in the use of these resources over and above the present level lead to a significant increase in gross returns.

Table.1 Input use pattern in Soybean cultivation (per acre)

\begin{tabular}{|c|l|c|c|}
\hline S. No. & \multicolumn{1}{|c|}{ Particulars } & Units/acre & $\begin{array}{c}\text { Soybean } \\
\text { N=60 }\end{array}$ \\
\hline 1 & Seeds & Kgs & 31 \\
\hline 2 & Human labour & Man days & 19 \\
\hline 3 & Bullock labour & Pair days & 3.22 \\
\hline 4 & Machine labour & Hours & 2.50 \\
\hline 5 & FYM & Tonnes & 1.75 \\
\hline 6 & Fertilizers & Kgs & 145.50 \\
\hline 7 & PPC & $₹$ & 160.00 \\
\hline
\end{tabular}


Table.2 Operation wise labour utilization pattern in Soybean cultivation (per acre)

\begin{tabular}{|c|c|c|c|c|}
\hline \multirow[t]{3}{*}{ Sl. No } & \multirow[t]{3}{*}{ Particulars } & \multicolumn{3}{|c|}{ Farmers } \\
\hline & & \multicolumn{3}{|c|}{$(\mathrm{N}=60)$} \\
\hline & & HL & BL & ML \\
\hline 1 & Ploughing & 1 & 1.22 & 1.5 \\
\hline 2 & Harrowing & 1 & 0 & 1 \\
\hline 3 & $\begin{array}{l}\text { Loading, transportation and spreading } \\
\text { organic manure }\end{array}$ & 3 & 0 & 0 \\
\hline 4 & Sowing & 3 & 2 & 0 \\
\hline 5 & Fertilizer Application & 3 & 0 & 0 \\
\hline 6 & Weeding & 3 & 0 & 0 \\
\hline 7 & Inter cultivation & 1 & 0 & 0 \\
\hline 8 & PPC application & 1 & 0 & 0 \\
\hline 9 & Harvesting & 3 & 0 & 0 \\
\hline & Total & 19 & 3.22 & 2.5 \\
\hline
\end{tabular}

Note: HL- Human Labour BL- Bullock Labour ML- Machine Labour

Table.3 Resource use efficiency of inputs in Soybean (Per acre)

\begin{tabular}{|c|c|c|c|}
\hline \multirow[t]{2}{*}{ SI. No. } & \multirow[t]{2}{*}{ Explanatory variables } & \multirow[t]{2}{*}{ Parameters } & Farmers \\
\hline & & & $(\mathrm{N}=60)$ \\
\hline 1. & Intercept & $\mathrm{a}$ & $\begin{array}{c}6.82 \\
(2.96)\end{array}$ \\
\hline 2. & Seeds (rs) & $b_{1}$ & $\begin{array}{l}-0.41 \\
(0.67)\end{array}$ \\
\hline 3. & Human labour (rs) & $\mathrm{b}_{2}$ & $\begin{array}{c}0.19 \\
(0.20)\end{array}$ \\
\hline 4. & Bullock labour (Rs) & $\mathrm{b}_{3}$ & $\begin{array}{c}0.09 * * \\
(0.10)\end{array}$ \\
\hline 5. & Machine labour (Rs) & $\mathrm{b}_{4}$ & $\begin{array}{l}-0.16 \\
(0.11)\end{array}$ \\
\hline 6. & FYM (Rs) & $b_{5}$ & $\begin{array}{c}2 . .54 * * * \\
(0.38)\end{array}$ \\
\hline 7. & Fertilizers (Rs) & $\mathrm{b}_{6}$ & $\begin{array}{l}-0.03 \\
(0.22)\end{array}$ \\
\hline 8. & PPC (Rs) & $\mathrm{b}_{7}$ & $\begin{array}{l}1.15^{* * *} \\
(0.09)\end{array}$ \\
\hline 9. & Coefficient of Multiple determination $\left(\mathrm{R}^{2}\right)$ & 92.56 & \\
\hline 10. & Returns to Scale $\left(\Sigma b_{\mathrm{i}}\right)$ & 3.37 & \\
\hline
\end{tabular}

Note: Figures in the parentheses indicates their respective standard errors ***-Significant at one per cent probability level

** Significant at five per cent probability level 
Table.4 MVP to MFC ratios of resources in Soybean Production

\begin{tabular}{|c|l|c|c|}
\hline SI. No & \multicolumn{1}{|c|}{ Explanatory variable } & Parameters & $\begin{array}{c}\text { Farmers } \\
(\mathbf{N}=60)\end{array}$ \\
\hline 1 & Seeds & $\mathrm{b}_{1}$ & -0.59 \\
\hline 2 & Farm yard manure & $\mathrm{b}_{2}$ & 0.27 \\
\hline 3 & Human labour & $\mathrm{b}_{3}$ & 0.13 \\
\hline 4 & Bullock labour & $\mathrm{b}_{4}$ & -0.23 \\
\hline 5 & Machine labour & $\mathrm{b}_{5}$ & 3.60 \\
\hline 6 & Fertilizers & $\mathrm{b}_{6}$ & -0.05 \\
\hline 7 & PPC & $\mathrm{B}_{7}$ & 2.21 \\
\hline
\end{tabular}

Note: MVP - Marginal Value Product, $\quad$ MFC - Marginal Factor Cost

Table 4 provides the details of allocative efficiency in Soybean cultivation. The ratio of Marginal value Product (MVP) to Marginal Factor Cost (MFC) was computed for each of the factor of production to draw some inference about the allocative efficiency (Table 3). The MVP to MFC ratio for Seed ($0.59)$, FYM (0.27), Human labour (0.13), Bullock labour (-0.23), Fertilizer (-0.05) were less than 1 hence the resources in study area was over utilized and machine labour (3.60) and PP chemicals (2.21) were showing more than one hence these resources are underutilized hence there is scope for increasing these resources.

The findings of the study clearly revealed the total cost increased with the increase in the farm size. Input Used pattern per hectare of Soybean cultivation shows that there is scope to increase FYM and machine labour.

The regression coefficient of seed $(-0.41)$ Machine labour (-0.16) and fertilizer was negative, indicating that increase in use of seeds, machine labour and fertilizer reduction in gross returns hence it is advisable to reduce applicable of these inputs. And it is very important to notice machine labour (3.60) and PP chemicals (2.21) were showing more than one hence these resources are underutilized hence there is scope for increasing these resources.

\section{References}

Ankita Parekh, Ravi Dsouza and Kunal Shah, 2012. Soybean seasonal report. Oct-102012.1-15.

David, T. A. and Terwase, S. 2011. Efficiency of resource use in rice farming enterprise in Kwande local Government area of Benue State, Nigeria. Int. J. Humanities So. Sci., 1(3): 215-220.

Handerson, J.M. and Quandt, R.E. 1971. Microeconomic theory- A mathematical approach (2nd Ed.), McGraw Hill Company Limited, NEW YORK, U.S.A.

Karthick, V., Alagumani, T. and Amarnath J. S. 2013. Resource use efficiency and technical efficiency of Turmeric Production in Tamil Nadu - A Stochastic Frontier Approach. Agric. Econ. Res. Rev., 26(1): 109-114.

Mahantesh, N., 2002. Economic and environmental issues related to use of agrochemicals in Cotton production in Belgaum district. M. Sc. (Agri.) Thesis, Univ. Agric. Sci., Dharwad, Karnataka (India)

Naik, A. D., Shankramurthy, H. G., Teggi, M. Y. and Koppad, M. B. 1998. Resource use efficiency in onion cultivation in Bijapur district, Karnataka. Kar. J. Agric. Sci., 11(1): 277.

Neelappa, 2002. Technical and allocative 
efficiency of paddy production in TBP area- An Economic analysis. M. Sc. (Agri.) Thesis, Univ. Agric. Sci., Dharwad Karnatak (India)

Rajur, B. C., Patil, B. L., and Basavaraj, H., 2007, Economics of chilli production in Karnataka. Karnataka J. Agric. Sci., 21 (2)237-240.

Sen, S.R. 1967. Growth and Instability in Indian agriculture, J. Ind. Soc. Agric. Stat., 19(1):1-30.

Suresh and Keshavareddy, T. R. 2006. Resource-use efficiency of Paddy cultivation in Peechi Command Area of Thrissur District of Kerala: An Economic Analysis. Agric. Econ. Res. Rev., 19: 159-171.

Taru, V. B., Kyagya, I. Z., Mshelia, S. I. and Adebayo, E. F. 2008. Economic efficiency of Resource use in Groundnut production in Adamawa state in Nigeria. World. J. Agric. Sci.,
4(3): 896-900.

Udaykumar Hosamani, Basavaraj, H. and Guledgudda, S. S., 2010. Cost, returns and resource use efficiency of pesticides in paddy production in Koppal district of Karnataka. Agric. Situ. India, 67 (4): 189-192.

Vani, B. P. and Vyasulu Vinod, 1996. Growth variability and instability of these major cereal crop in Karnataka. Econ. Pol. Weekly. 26 (31): 474-483.

Veeranagouda Goudar, Havaldar, Y. N., Hosamani, S. B. and Basavaraj Bankar, 2011. Growth rate scenari of chilli in Karnataka. Karnataka J. Agric. Sci., 24 (3):412-413.

Wadear, 2003. Animal based farming systems for long-term sustainability in Northern Karnataka: A socio economic assessment. Ph. D. Thesis, Univ. Agric. Sci., Dharwad, Karnataka (India).

\section{How to cite this article:}

Vasudeva Naik, K., Vinayaka Jalikatti, Raghavendra Chourad and Ashok, N. 2018. Resource Use Efficiency of Soybean in Belagavi District of Karnataka, India. Int.J.Curr.Microbiol.App.Sci. 7(01): 2155-2161. doi: https://doi.org/10.20546/ijcmas.2018.701.259 